Published in final edited form as:

Horm Metab Res. 2012 July ; 44(8): 569-576. doi:10.1055/s-0032-1306343.

\title{
Convergence of Multiple Mechanisms of Steroid Hormone Action
}

\author{
S. K. Mani ${ }^{1,{ }^{*}}$, P. G. Mermelstein ${ }^{2,{ }^{*}}$, M. J. Tetel ${ }^{3,{ }^{*}}$, and G. Anesetti ${ }^{4,}{ }^{*}$ \\ ${ }^{1}$ Department of Molecular \& Cellular Biology and Neuroscience, Baylor College of Medicine, \\ Houston, TX, USA \\ ${ }^{2}$ Department of Neuroscience, University of Minnesota, Minneapolis, MN, USA \\ ${ }^{3}$ Neuroscience Program, Wellesley College, Wellesley, MA, USA \\ ${ }^{4}$ Departamento de Hostologia y Embriologia, Facultad de Medicine, Universidad de la Republica, \\ Montevideo, Uruguay
}

\begin{abstract}
Steroid hormones modulate a wide array of physiological processes including development, metabolism, and reproduction in various species. It is generally believed that these biological effects are predominantly mediated by their binding to specific intracellular receptors resulting in conformational change, dimerization, and recruitment of coregulators for transcription-dependent genomic actions (classical mechanism). In addition, to their cognate ligands, intracellular steroid receptors can also be activated in a "ligand-independent" manner by other factors including neurotransmitters. Recent studies indicate that rapid, nonclassical steroid effects involve extranuclear steroid receptors located at the membrane, which interact with cytoplasmic kinase signaling molecules and G-proteins. The current review deals with various mechanisms that function together in an integrated manner to promote hormone-dependent actions on the central and sympathetic nervous systems.
\end{abstract}

\section{Keywords}

estrogen; progesterone; signaling; cross-talk; ovary; brain

\section{Introduction}

Steroid hormones, estradiol $\left(\mathrm{E}_{2}\right)$ and progesterone $(\mathrm{P})$, regulate important physiological processes including development, differentiation, metabolism, reproduction, learning, and memory in various species. The biological effects of $\mathrm{E}_{2}$ and $\mathrm{P}$ are primarily mediated by binding to their classical intranuclear receptors, estrogen (ERs) and progestin receptors (PRs) that act as ligand-inducible transcription factors and interact with steroid receptor coregulators to modulate target gene expression and function. Interestingly, not all the "classical" receptors are intranuclear and can be associated at the membrane. As described in this review, extranuclear ERs and PRs at the membrane or in the cytoplasm can interact with $\mathrm{G}$ proteins and signaling kinases, and other $\mathrm{G}$ protein coupled receptors, to mediate rapid effects of the hormones. The rapid actions involving cytoplasmic kinase signaling and/

\footnotetext{
(C) Georg Thieme Verlag KG Stuttgart · New York

Correspondence S. K. Mani, Department of Molecular \& Cellular Biology, Baylor College of Medicine, One Baylor Plaza, Houston, Texas 77030, USA, Tel.: +1/713/798 6647, Fax: +1/713/790 1275, smani@ bcm.tmc.edu.

*All the authors contributed equally to this work.
} 
or extranuclear steroid receptors can result in both transcription-independent and transcription-dependent actions. In addition, to their cognate ligands, intranuclear steroid receptors (PRs) can also be activated in a "ligand-independent" manner by neurotransmitters (dopamine; DA). In this review, the distinct classical and nonclassical cellular and molecular mechanisms of steroid hormone action will be discussed with specific reference to E2 and P effects in central and sympathetic nervous systems (Fig. 1).

\section{Mechanisms of Progesterone Action in Brain}

Ovarian steroid hormones, $\mathrm{E}_{2}$ and $\mathrm{P}$ regulate cellular functions in the central nervous system resulting in alterations in physiology and reproductive behavior. As in other steroid-sensitive tissues, the regulatory action of $\mathrm{E}_{2}$ on behavior is believed to involve the activation of ERs, altering the expression of a number of genes, including PR gene. Progestins, including P, exert their physiological effects primarily by binding to $E_{2}$-induced, intracellular PRs, which function as transcriptional factors, regulating the expression of genes and genomic neural networks to initiate and/or sustain physiological response [1,2]. PRs undergo significant conformational change upon binding by $\mathrm{P}$, leading to their nuclear translocation, dimerization and DNA binding [3]. When bound to DNA, PRs interact with basal transcriptional machinery, assisted by coactivator molecules to initiate chromatin remodeling [4-6]. Phosphorylation of the coactivators also plays a crucial role in the activation of steroid receptors $[7,8]$. The role of coactivators is discussed below.

Spatial, temporal, and functional correlations indicate that $\mathrm{E}_{2}$-induced PRs function as transcriptional mediators and regulate transcription of target genes to affect reproductive behavior [2]. The time course of activation and termination of reproductive behavior has also been shown to parallel $\mathrm{E}_{2}$-induced increase and decline in PRs in the hypothalamus and the preoptic areas of the brain. A wide body of literature has identified different neuroanatomical sites in the regulation of female sexual behavior by steroid hormones [9]. Studies using PR antagonists, protein and RNA synthesis inhibitors, antisense to oligonucleotides to PRm-RNA and PR mutant mice indicate a requirement for classical genomic mode of activation involving intracellular PRs in P-mediated facilitation of reproductive behavior [10-15].

Studies have also demonstrated that PRs can be activated by factors other than their cognate ligand, P (ligand-independent activation). Second messenger molecules, including $3^{\prime}, 5^{\prime}$ cyclic adenosine monophosphate (cAMP), $3^{\prime}, 5^{\prime}$-cyclic guanosine monophosphate (cGMP), nitric oxide (NO), and neurotransmitter (dopamine, DA) can substitute for $\mathrm{P}$ in the facilitation of reproductive behavior [16,17]. Using PR antagonists, antisense oligonucleotides and null mutants for PRs, the critical requirement of classical PRs as transcriptional mediators in the cross talk between $\mathrm{P}$ and DA-initiated pathways in the facilitation of female sexual receptive behavior has been demonstrated $[18,19]$. In addition, DA-initiated second messenger signaling cascade was demonstrated to involve the activation of protein kinase A (PKA) and neuronal phosphoprotein, dopamine and cAMP regulated phosphoprotein-32 (DARPP-32) [20]. This signaling mechanism could potentially lead to the alterations in the phosphorylation dynamics and activation of PRs and/or its coregulators as discussed below.

While genomic effects characterized by a delayed onset have traditionally been assumed to be the primary pathway for $\mathrm{P}$ action in the brain, recent studies suggest the involvement of "nonclassical" mechanisms of progesterone action. These nonclassical short-latency effects of progesterone widely affect cell functioning, through modulation of putative cell surface receptors, ion channels and mechanisms coupled to cytoplasmic second messenger signaling cascades, independent of gene transcription [21-23]. In addition to P, several of its ring-A 
reduced metabolites have been shown to facilitate lordosis response in ovariectomized, $\mathrm{E}_{2-}$ primed female rats via activation of MAPK pathway [17]. A number of laboratories have reported the involvement of at least 4 extranuclear kinase systems, PKA, PKC, CaMKII, and PKG in the rapid P effects in the VMH and POA of the female rat [16,17,21,24-27]. Since the initiation of these nonclassical effects occurs rapidly (in seconds or minutes) and is triggered at the membrane surface, the classical model of nuclear PR-mediation is inadequate to account for these effects. Recent evidence suggests the involvement of 2 types of novel membrane proteins unrelated to classical PRs, progesterone membrane receptor component 1 (PGMRC1) and progesterone membrane receptors (mPRs), in P signaling in several reproductive tissues and in the brain [28,29]. Inhibition of MAPK signaling pathway results in reduction of $\mathrm{P}$, dibutyryl-cAMP (db-cAMP)-, prostaglandin $\mathrm{E}_{2}\left(\mathrm{PGE}_{2}\right)-$, or GnRHfacilitated female reproductive behavior in rats [17]. These studies suggest that $E_{2}$ and $P$ actions in the brain could involve rapid activation of multiple signal transduction pathways that converge with classical genomic pathways.

\section{Nuclear Receptor Coactivators: The p160 Steroid Receptor Coactivator Family}

In the classic genomic mechanism of action discussed above, nuclear receptor coregulators enhance (coactivators) or repress (corepressors) the steroid receptor transcriptional activity. Over 300 coactivators have been identified, many of which have been shown to function in physiology, behavior and human disease [30]. This review will focus on the role of the steroid receptor coactivator family in metabolism and brain and behavior.

The steroid receptor coactivator (SRC) family of p160 proteins consists of SRC-1 (NcoA-1), SRC-2 (GRIP1/TIF2/NCoA-2), and SRC-3 (AIB1/TRAM-1/ACTR/RAC3/pCIP). This SRC family of coactivators physically interacts with steroid receptors, including receptors for androgens (AR), estrogens (ER), progestins (PR), and glucocorticoids (GR), in a liganddependent manner [31]. The $\mathrm{C}$-terminus of the SRCs contains 2 activation domains (AD-1 and AD-2), while the N-terminus contains a third activation domain (AD-3) and a bHLHPAS motif (basic helix loop helix-Per Arnt Sims), which is the most conserved domain within this family of proteins. The activation domains interact with secondary coactivators known as co-coactivators. These co-coactivators act as bridging molecules between the receptor and the general transcription machinery and modify chromatin within the promoter and enhancer regions by histone acetylation and methylation [31].

\section{The p160 SRC Family in Metabolism}

All 3 members of the p160 family of coactivators are involved in metabolic homeostasis. SRC-1 is critical in maintaining energy balance by regulating both energy intake and expenditure [32]. In support, SRC-1 knockout mice have decreased energy expenditure and a reduced thermogenic capacity and thus, are prone to obesity. One proposed mechanism of action for SRC-1 in metabolism is through its interactions with PPAR $\gamma$ coactivator-1a (PGC-1a), an important regulator of mitochondrial biogenesis and oxidative phosphorylation [32]. In contrast to SRC-1, SRC-2 knockout mice are leaner than wild type mice and have an increase in adaptive thermogenesis [33]. It has been suggested that the absence of SRC-2 results in enhanced interaction between SRC-1 and PGC-1a, which increases thermogenic activity. Thus, it has been proposed that the ratio of SRC-1 and SRC-2 plays a role in maintaining the balance of energy expenditure and adipogenesis through controlling PGC-1 $a$ activity [33]. SRC-3 knockouts have lower body fat content compared with wild-type mice [32]. SRC-3 mediates the transcriptional activity of PPAR $\gamma 2$, which is important for adipocyte differentiation [33]. In support, adipocyte differentiation and adipogenesis are impaired in mouse embryonic fibroblasts from cells isolated from 
SRC-3 knockout mice or from 3T3-L1 adipocyte cells with decreased levels of SRC-3 [33]. Taken together, these studies suggest that the 3 members of the p160 SRC family play an important role in energy homeostasis.

\section{The p160 SRC Family in Brain and Behavior}

A variety of recent studies indicate that 2 of the p160 SRC family members, SRC- 1 and SRC-2, are important for hormone action in brain and the regulation of behavior [34]. SRC-1 and SRC-2 are expressed at high levels in the hypothalamus, cortex and hippocampus of rodents [34-43] and birds [44-47]. Interestingly, in contrast with the other members of the SRC family, SRC-3 is expressed sparsely in the hypothalamus [48]. In order for SRC-1 and SRC-2 to function with steroid receptors in brain, both the coactivator and receptor must be expressed in the same cells. In support, SRC-1 and SRC-2 are expressed in the majority of estradiol-induced PR cells in regions involved in metabolism and behavior, including the ventromedial hypothalamus $(\mathrm{VMH})$, medial preoptic area and arcuate nucleus in rodents [35,49]. A variety of studies reveal that steroids influence the expression of these coactivators in brain [35,43,50-52]. Moreover, protein-protein interactions studies reveal that SRC-1 and SRC-2 from rodent brain physically associate with ER and PR in a receptor subtype- and brain region-specific manner [53,54].

A variety of studies using antisense to SRC-1 or SRC-2 mRNA indicate that these coactivators are important for hormone dependent brain development and behavior. SRC-1 is critical for normal development of hormone-dependent sexual differentiation of the brain and adult sexual behavior [40]. In the adult brain, SRC-1 and SRC-2 function in the VMH to modulate ER-mediated transactivation of the behaviorally-relevant PR gene [48,55]. In addition, SRC-1 functions in the VMH to influence distinct ER- and PR-dependent aspects of female sexual behavior [56]. Interestingly, reduction of SRC-1 expression in this brain region by antisense altered PR function and reduced PR-dependent proceptivity (behavior by the female to solicit interaction by the male), but not PR-dependent receptivity [56]. These findings suggest that reduction of SRC-1 by antisense disrupted the activity of PR signaling pathway(s) that influence proceptivity, while alternate PR signaling pathways, that regulate PR-dependent receptivity, remained intact and functional. These coactivators, and others, have also been found to be essential in hormone action in brain and behavior of birds [57,58].

The p160 family of nuclear receptor coactivators has a critical role in modulating steroid receptor action at the cellular level. In the future, it will be important to determine the role of these coactivators in nonclassical and membrane steroid signaling in brain discussed above and below, respectively. A better understanding of how these important coactivators function in brain is crucial to understanding the complex regulation of behavior and physiology by steroids.

\section{Membrane Estrogen Receptors Activate Metabotropic Glutamate Receptor Signaling}

While we continue to appreciate the diversity of signaling regarding the actions of nuclear $\mathrm{ERa}, \mathrm{ER} \beta$ and their associated proteins, estrogen receptors are also trafficked to the surface membrane, whereby they regulate various intracellular signaling pathways. Membraneinitiated estrogen action, both inside and outside of the nervous system has been described for quite some time $[59,60]$. Yet, the identity of these membrane associated receptors has for years remained controversial [61]. Several studies have suggested unique estrogen receptors acting at the membrane to initiate intracellular signaling [62-64], while others have reported that these G-protein coupled receptors, localized to endoplasmic reticulum, are not activated 
by $E_{2}$ and have no effect on intracellular signaling [65]. That said, in most systems, membrane-initiated steroid hormone action appears due to the activation of a subpopulation of ERa and ER $\beta$ that have been modified to traffic and act at the neuronal surface $[66,67]$. Determining how ERa and ER $\beta$ act at the membrane to affect intracellular signaling and how these estrogen receptors are trafficked to the membrane is critical to understanding estrogen action in brain.

Recent studies have focused on estradiol-mediated phosphorylation (i.e., activation) of the transcription factor CREB $[68,69]$. Phosphorylation of CREB is an important convergence point in cell signaling, and is involved in various forms of neuronal plasticity, including learning and memory, drug addiction and nociception [70], processes also under the influence of estrogens [61]. Work across multiple laboratories has indicated that activation of surface estrogen receptors leads to CREB phosphorylation via stimulation of the MAPK/ ERK signaling pathway [71-73]. Furthermore, estrogen receptor knockout mice do not exhibit estrogen-dependent CREB phosphorylation, indicating the dependence upon ERa and ER $\beta$ [74].

To elucidate the signaling mechanisms by which estradiol affects CREB phosphorylation, initial studies utilized primary cultures from rat hippocampus [75]. Estradiol stimulation of membrane ERa was found to initiate mGluR1 signaling. These actions of estradiol/ERa on mGluR1 were independent of glutamate and only occurred in cultures generated from female rats. ERa activation of mGluR1 signaling led to CREB phosphorylation via Gqmediated stimulation of phospholipase C (PLC), protein kinase C (PKC) and inositol trisphosphate (IP3). Interestingly, this was not the only membrane-initiated signaling pathway sensitive to estradiol. In these same neurons, estradiol-mediated activation of ERa or ER $\beta$ would lead to activation of mGluR2. Activation of these Gi/o G protein-coupled receptors by estradiol would lead to an attenuation of L-type calcium channel-mediated CREB phosphorylation. This was consistent, as well as provided a mechanism, regarding previous findings of estradiol inhibition of L-type calcium channels [76].

While CREB phosphorylation is only one of many downstream targets of mGluR activation, it was somewhat surprising to observe estradiol regulating opposing processes within the same cell. That is, at least, if gonadal estrogens are the principal activators of ER/mGluR signaling. However, recent work has provided several clues that brain-derived estrogen (i. e., neuroestrogen) may be the critical mediator of rapid estrogen signaling [77]. Specifically, not only does estradiol directly affect the electrochemical state of the cell, but also synthesis of estradiol from aromatase localized to presynaptic boutons suggests estradiol may act as a neurotransmitter [78-81]. A universal characteristic of neurotransmission is that the ligand release point is proximal to the location of the cognate receptor. Thus, if ER/mGluR signaling acts as similar to a traditional neurotransmitter system, these signaling proteins must also be spatially restricted. In fact, caveolin- 1 expression was found to be essential for the functional coupling of ERa with mGluR1a, whereas, caveolin-3 is necessary for ERa and ER $\beta$ activation of mGluR2 [68]. Hence, the spatial segregation of different ER/mGluR signaling pathways can allow for independent activation and inhibition of CREB phosphorylation.

Because membrane estrogen receptor signaling is widespread both inside and outside of the nervous system, it was determined whether ERs were coupled to mGluR signaling in other brain regions. Similar to previous results in hippocampal cultures, bidirectional effects of estradiol on CREB phosphorylation, dependent on ER/mGluR signaling, were found in striatal neurons [68]. Moreover, opposing ER/mGluR processes related to CREB phosphorylation were similarly segregated by expression of either caveolin-1 or caveolin-3. Surprisingly, however, the mGluRs responsible for membrane estrogen receptor signaling in 
striatum were different. In substitution of mGluR1a, ERa was functionally coupled to mGluR5 in striatal neurons, whereas ERa and ER $\beta$ were paired with mGluR3 as opposed to in hippocampus where these ERs activated mGluR2. These results are interesting as each of these 4 mGluRs is expressed in both hippocampus and striatum. These data suggest ERs may be promiscuous regarding their coupling to various $\mathrm{G}$ protein-coupled receptors.

Trafficking of ERa and ER $\beta$ to the membrane appears dependent upon palmitoylation. Palmitoylation is the reversible addition of the fatty acid palmitate to a protein.

Palmitoylation affects the subcellular distribution and function of the modified protein, including promoting protein localization to membranes. Palmitoylation occurs most commonly on cysteine residues, and is mediated by a family of proteins called palmitoyl acyltransferases (PATs). There are 23 unique PATs, each derived from a separate gene (DHHC 1-9, 11-24). Previous work in cell lines demonstrated ERa incorporates radiolabeled palmitate [82]. Substitution of the palmitoyl cysteine residue with alanine blocks both radiolabeling of ERa as well as membrane-initiated ERa responsiveness [82-84]. In neurons, recent findings indicate that palmitoylation of ERa and ER $\beta$ is essential for membrane ER localization, association with caveolin proteins, and activation mGluR signaling [81].

Using a simplified model system (i. e., cultured neurons) it has been possible to identify this potential mechanism of estrogen action in brain. Work from a number of labs has expanded the importance of these studies to the whole animal, to additional brain regions, and correspondingly, to additional behaviors. The first report demonstrating the importance of $\mathrm{ER} / \mathrm{mGluR}$ signaling related to membrane estrogen action on the regulation of rat lordosis [85]. Specifically, within the arcuate nucleus, ERa activation of mGluR1 signaling is essential for full sexual receptivity. In a separate study, regulation of the estrous cycle by membrane ERs is dependent on ERa activation of mGluR1 in hypothalamic astrocytes [86]. Examining dorsal root ganglion neurons in a model of nociception, estrogen receptor activation of mGluR2/3 attenuates ATP-induced increases in intracellular calcium via inhibition of L-type calcium channels [87]. Additionally, estrogen-induced masculinization of the medial preoptic area is dependent upon mGluR [88]. ER/mGluR signaling has also been demonstrated to affect spinogenesis [89], and recent findings indicate ER/mGluR coupling is responsible for estrogen-induced release of endocannabinoids in hippocampal neurons [90] and the potentiation of dopamine release in the female striatum following the administration of a psychostimulant [91]. Over the next several years, it is likely that other membrane actions of estradiol will also be shown dependent upon activation of mGluRs.

\section{Estrogens and Sympathetic Innervation in Female Reproductive System}

In addition to the variety of mechanisms by which estrogens act in brain to regulate female reproductive behavior discussed above, estradiol influences the function of sympathetic neurons associated with reproductive organs in a variety of ways. The sympathetic system includes preganglionic neurons located in the intermediolateral column at the thoracic and lumbar levels of the spinal cord, which synapse with postganglionic neurons located in sympathetic ganglia. Axonal projections of these neurons are dependent on several guidance and survival signals provided by target organs [92]. These neurons display immunoreactivity for one or both of the ER subtypes [93,94]. While almost all sympathetic neurons express $E R \beta$, only about a third of these neurons express ERa [95]. In some instances sympathetic neurons in lumbar paravertebral and prevertebral ganglia display cytoplasmic ERimmunoreactivity $[94,96]$. This cytoplasmic distribution has been attributed to the presence of ERa isoforms lacking nuclear localization signals and thus unable to respond to estrogens [97]. The membrane ER, GPR30, may also mediate signaling. Immunohistochemical and in situ hybridization studies reveal expression of GPR30 in some regions of brain, spinal cord 
and peripheral tissues [98]. However, it is not known if GPR30 are expressed or function in postganglionic sympathetic neurons.

Sympathetic fibers that innervate the ovary originate mainly from the complex celiacmesenteric ganglia. Ovarian innervation is associated with growing follicles, interstitial tissue and ovarian vasculature [99]. Two of the major neurotransmitters contained in the ovarian nerves, norepinephrine (NE) and vasoactive intestinal polypeptide (VIP), are considered modulators of steroid production [100]. Several studies show the relevance of neural sympathetic influence on follicular assembly, acquisition of responsiveness to gonadotropins and regulation of ovarian steroidogenesis [101,102].

Estradiol produced by growing ovarian follicles has significant paracrine and autocrine effects that can influence gonadal physiology. Estrogen action is mediated by ERs in follicular structures and the stroma of the ovary. ER $\beta$ expression in granulosa cells is essential for cell differentiation and function [103], while ERa expressed in thecal and interstitial cells are crucial for steroidogenesis [104].

Some effects of estradiol on sympathetic innervation are mediated by changes in the expression of neurotrophins, including nerve growth factor (NGF), a signaling molecule involved in survival and differentiation of sympathetic and sensorial neurons. In the rat ovary, neurotrophins are produced in cells of the follicular wall and are responsible for the development of ovarian sympathetic innervation [105]. The actions of these neurotrophins are mediated by 2 receptors: 1) the $75 \mathrm{kDa}$ low-affinity neurotrophin receptor (p75NGFR), which displays rapid association and dissociation with most members of the neurotrophin family and 2) a high-affinity tyrosine kinase (TrkA) receptor, which binds NGF more specifically but with slow kinetics [106]. Estrogen-responsive elements have been identified in many of the genes that code for neurotrophins or their receptors [107]. NGF production induced by estradiol exposure may differ depending on the tissue being analyzed [108]. In addition, variations in estrogen levels alter neurotrophin receptor expression in sympathetic neurons, thus modulating neurotrophin responsiveness. This neurotrophin response varies with the neuronal population analyzed, the doses administered and the physiological status of animals (e. g., prepubertal, adult cyclic, or adult pregnant rat) [94,109].

Mounting evidence indicates that changes in estrogen signaling and adrenergic innervation can induce alterations in sympathetic tone. The most dramatic modifications are seen in the myometrial layer of uterus, where variations in levels of estrogens during the rodent estrous cycle and pregnancy induce changes in sympathetic nerve density, including a progressive loss of sympathetic activity at late gestation [110]. In the ovary, estradiol treatment induces an augmented synthesis of NGF associated with an increase in norepinephrine content that can induce long-lasting effects on the sympathetic innervation of the ovaries. These changes alter ovarian morphology and function; induce the development and maintenance of cystic follicles, and cause anovulation and alterations in estrous cyclicity [111,112]. Similar changes are found in ovaries from women with polycystic ovary syndrome (PCOS), a common cause of infertility during reproductive age [113]. In animal models of PCOS, the effects induced by estradiol exposure can be partially reversed by surgical sympathectomy $[111,114]$. A potential contribution of the sympathetic system to PCOS has been suggested given that polycystic ovaries show an increase in the number of sympathetic fibers [115] and ovarian wedge resection or laparoscopic laser cauterization are effective in increasing the ovulatory response in women with PCOS [116]. These findings raise the possibility that sympathetic input may play a role in the development and maintenance of polycystic ovaries in PCOS women. 
In summary, estradiol can regulate several aspects of sympathetic neuronal function through a variety of mechanisms. Neuronal target tissues can be influenced by these estradiolinduced changes. While estrogens can have direct effects by acting through neuronal ERs, they can also act indirectly to elicit changes in production of survival signals in target organs that affect the function of subpopulations of neurons. Knowledge of the basic mechanisms of this crosstalk is essential in understanding the pathophysiological aspects involved in the development and maintenance of complex hormone-dependent disorders affecting human health.

\section{Conclusions}

The research outlined in this review (e. g., mechanisms of PR activation, transcriptional coactivators, membrane/nuclear signaling, neuronal feedback to the reproductive organs) reflects how far the field of neuroendocrinology has progressed over the last several years. Clearly, steroid hormone action in the nervous system is not a simple on/off activational relay. Based upon the role these hormones play in a diversity of physiological responses, this is not surprising. Over the next several years, we can expect basic science to provide additional breakthroughs as these findings are integrated into a comprehensive study of endocrine and neuroendocrine responsiveness. This work will ultimately impact the treatment of various hormonal and metabolic disorders.

\section{Acknowledgments}

The studies contributed to this work were supported by Public Health Service grants from National Institutes of Health HD 062512 (SKM), National Institutes of Health R01 DK61935 (MJT), National Institute of Health NS 041302 and core funding NS 062125 (PGM), and grants from National Science Foundation IBN 0080818 (MJT).

\section{References}

1. Blaustein, JD.; Olster, DH. Gonadal steroid hormone receptors and social behaviors. In: Balthazar, J., editor. Molecular and cellular basis of social behavior in vertebrates. Berlin: Springer-Verlag; 1989. p. 31-104.

2. pfaff, DW.; Ogawa, S.; Kia, K.; Vasudevan, N.; Krebs, C.; Frohlich, J.; Kow, LM. Genetic mechanisms in neural and hormonal controls over female reproductive behaviors. In: pfaff, DW.; Arnold, AP.; Etgen, AM.; Fahrbach, SE.; Rubin, RT., editors. Hormones, Brain and Behavior. San Diego: Academic Press; 2002. p. 441-510.

3. Tsai MJ, O'Malley BW. Molecular mechanisms of action of steroid/thyroid receptor superfamily members. Annu Rev Biochem. 1994; 63:451-486. [PubMed: 7979245]

4. Horwitz KB, Tung L, Takimoto GS. Novel mechanisms of antiprogestin action. Acta Oncol. 1996; 35:129-140. [PubMed: 8639307]

5. Katzenellenbogen JA, O'Malley BW, Katzenellenbogen BS. Tripartite steroid hormone receptor pharmacology: interaction with multiple effector sites as a basis for the cell- and promoter-specific action of these hormones. Mol Endocrinol. 1996; 10:119-131. [PubMed: 8825552]

6. McKenna NJ, Lanz R, O’Malley BW. Nuclear receptor coregulators: cellular and molecular biology. Endocr Rev. 1999; 20:321-344. [PubMed: 10368774]

7. Rowan BG, Garrison N, Weigel NL, O'Malley BW. 8-Bromo-cyclic AMP induces phosphorylation of two sites in SRC-1 that facilitate ligand-independent activation of the chicken progesterone receptor and are critical for functional cooperation between SRC-1 and CREB binding protein. Mol Cell Biol. 2000; 20:8720-8730. [PubMed: 11073973]

8. Rowan BG, Weigel NL, O'Malley BW. Phosphorylation of steroid receptor coactivator-1. Identification of the phosphorylation sites and phosphorylation through the mitogen-activated protein kinase pathway. J Biol Chem. 2000; 275:4475-4483. [PubMed: 10660621]

9. Blaustein, JD.; Erskine, MS. Feminine sexual behavior: Cellular integration of hormonal and afferent information in the rodent forebrain. In: pfaff, DW.; Arnold, AP.; Etgen, AM.; Fahrbach, 
SE.; Rubin, RT., editors. Hormones Brain and Behavior. New York: Academic Press, New York; 2002. p. 139-214.

10. Meisel RL, pfaff DW. RNA and protein synthesis inhibitors: effects on sexual behavior in female rats. Brain Res Bull. 1984; 12:187-193. [PubMed: 6202378]

11. Meisel RL, pfaff DW. Specificity and neural sites of action of anisomycin in the reduction or facilitation of female sexual behavior in rats. Horm Behav. 1985; 19:237-251. [PubMed: 4054850]

12. Brown TJ, Blaustein JD. Inhibition of sexual behavior in female guinea pigs by a progestin receptor antagonist. Brain Res. 1984; 301:343-349. [PubMed: 6539635]

13. Mani SK, Allen JM, Clark JH, Blaustein JD, O’Malley BW. Convergent pathways for steroid hormone- and neurotransmitter-induced rat sexual behavior. Science. 1994; 265:1246-1249. [PubMed: 7915049]

14. Ogawa S, Olazabal UE, Parhar IS, pfaff DW. Effects of intrahypothalamic administration of antisense DNA for progesterone receptor mRNA on reproductive behavior and progesterone receptor immunoreactivity in female rat. J Neurosci. 1994; 14:1766-1774. [PubMed: 8126569]

15. Pollio G, Xue P, Zanisi M, Nicolin A, Maggi A. Antisense oligonucleotide blocks progesteroneinduced lordosis behavior in ovariectomized rats. Brain Res Mol Brain Res. 1993; 19:135-139. [PubMed: 8361336]

16. Chu HP, Morales JC, Etgen AM. Cyclic GMP may potentiate lordosis behaviour by progesterone receptor activation. J Neuroendocrinol. 1999; 11:107-113. [PubMed: 10048465]

17. Gonzalez-Flores O, Gomora-Arrati P, Garcia-Juarez M, Gomez-Camarillo MA, Lima-Hernandez FJ, Beyer C, Etgen AM. Nitric oxide and ERK/MAPK mediation of estrous behavior induced by GnRH, PGE2 and db-cAMP in rats. Physiol Behav. 2009; 96:606-612. [PubMed: 19162055]

18. Mani SK, Allen JM, Lydon JP, Mulac-Jericevic B, Blaustein JD, DeMayo FJ, Conneely O, O'Malley BW. Dopamine requires the unoccupied progesterone receptor to induce sexual behavior in mice. Mol Endocrinol. 1996; 10:1728-1737. [PubMed: 8961281]

19. Mani SK, Blaustein JD, Allen JM, Law SW, O’Malley BW, Clark JH. Inhibition of rat sexual behavior by antisense oligonucleotides to the progesterone receptor. Endocrinology. 1994; 135:1409-1414. [PubMed: 7925102]

20. Mani SK, Fienberg AA, O'Callaghan JP, Snyder GL, Allen PB, Dash PK, Moore AN, Mitchell AJ, Bibb J, Greengard P, O'Malley BW. Requirement for DARPP-32 in progesterone-facilitated sexual receptivity in female rats and mice. Science. 2000; 287:1053-1056. [PubMed: 10669419]

21. Gonzalez-Flores O, Gomora-Arrati P, Garcia-Juarez M, Gomez-Camarillo MA, Lima-Hernandez FJ, Beyer C, Etgen AM. Nitric oxide and ERK/MAPK mediation of estrous behavior induced by GnRH, PGE2 and db-cAMP in rats. Physiol Behav. 2009; 96:606-612. [PubMed: 19162055]

22. Boonyaratanakornkit V, Bi Y, Rudd M, Edwards DP. The role and mechanism of progesterone receptor activation of extranuclear signaling pathways in regulating gene transcription and cell cycle progression. Steroids. 2008; 73:922-928. [PubMed: 18321550]

23. Schumacher M, Coirini H, Robert F, Guennoun R, El-Etr M. Genomic and membrane actions of progesterone: implications for reproductive physiology and behavior. Behav Brain Res. 1999; 105:37-52. [PubMed: 10553689]

24. Balasubramanian B, Portillo W, Reyna A, Chen JZ, Moore AN, Dash PK, Mani SK. Nonclassical mechanisms of progesterone action in the brain: I. Protein kinase $\mathrm{C}$ activation in the hypothalamus of female rats. Endocrinology. 2008; 149:5509-5517. [PubMed: 18617608]

25. Balasubramanian B, Portillo W, Reyna A, Chen JZ, Moore AN, Dash PK, Mani SK. Nonclassical mechanisms of progesterone action in the brain: II. Role of calmodulin-dependent protein kinase II in progesterone-mediated signaling in the hypothalamus of female rats. Endocrinology. 2008; 149:5518-5526. [PubMed: 18617607]

26. Petitti N, Etgen AM. Progesterone depression of norepinephrine-stimulated cAMP accumulation in hypothalamic slices. Brain Res Mol Brain Res. 1989; 5:109-119. [PubMed: 2541302]

27. Petitti N, Etgen AM. Alpha 1-adrenoceptor augmentation of beta-stimulated cAMP formation is enhanced by estrogen and reduced by progesterone in rat hypothalamic slices. J Neurosci. 1990; 10:2842-2849. [PubMed: 2167357] 
28. Falkenstein E, Meyer C, Eisen C, Scriba PC, Wehling M. Full-length cDNA sequence of a progesterone membrane-binding protein from porcine vascular smooth muscle cells. Biochem Biophys Res Commun. 1996; 229:86-89. [PubMed: 8954087]

29. Zhu Y, Rice CD, Pang Y, Pace M, Thomas P. Cloning, expression, and characterization of a membrane progestin receptor and evidence it is an intermediary in meiotic maturation of fish oocytes. Proc Natl Acad Sci USA. 2003; 100:2231-2236. [PubMed: 12574519]

30. Lonard DM, Kumar R, O'Malley BW. Minireview: the SRC family of coactivators: an entree to understanding a subset of polygenic diseases? Mol Endocrinol. 2010; 24:279-285. [PubMed: 19846539]

31. Johnson AB, O'Malley BW. Steroid receptor coactivators 1, 2 and 3: Critical regulators of nuclear receptor activity and steroid receptor modulator (SRM)-based cancer therapy. Mol Cell Endocrinol. 2011; 348:430-439. [PubMed: 21664237]

32. Louet JF, O'Malley BW. Coregulators in adipogenesis: what could we learn from the SRC (p160) coactivator family? Cell Cycle. 2007; 6:2448-2452. [PubMed: 17704643]

33. Chopra AR, Louet JF, Saha P, An J, DeMayo F, Xu J, York B, Karpen S, Finegold M, Moore M, Chan L, Newgard CB, O'Malley BW. Absence of the SRC-2 coactivator results in a glycogenopathy resembling Von Gierke's disease. Science. 2008; 322:1395-1399. [PubMed: 19039140]

34. Tetel MJ, Auger AP, Charlier TD. Who's in charge? Nuclear receptor coactivator and corepressor function in brain and behavior. Front Neuroendocrinol. 2009; 30:328-342. [PubMed: 19401208]

35. Tognoni CM, Chadwick JG Jr, Ackeifi CA, Tetel MJ. Nuclear receptor coactivators are coexpressed with steroid receptors and regulated by estradiol in mouse brain. Neuroendocrinology. 2011; 94:49-57. [PubMed: 21311177]

36. Misiti S, Schomburg L, Yen PM, Chin WW. Expression and hormonal regulation of coactivator and corepressor genes. Endocrinology. 1998; 139:2493-2500. [PubMed: 9564863]

37. Shearman LP, Zylka MJ, Reppert SM, Weaver DR. Expression of basic helix-loop-helix/PAS genes in the mouse suprachiasmatic nucleus. Neuroscience. 1999; 89:387-397. [PubMed: 10077321]

38. Martinez de Arrieta C, Koibuchi N, Chin WW. Coactivator and corepressor gene expression in rat cerebellum during postnatal development and the effect of altered thyroid status. Endocrinology. 2000; 141:1693-1698. [PubMed: 10803578]

39. Meijer OC, Steenbergen PJ, de Kloet ER. Differential expression and regional distribution of steroid receptor coactivators SRC-1 and SRC-2 in brain and pituitary. Endocrinology. 2000; 141:2192-2199. [PubMed: 10830308]

40. Auger AP, Tetel MJ, McCarthy MM. Steroid receptor coactivator-1 mediates the development of sex specific brain morphology and behavior. Proc Natl Acad Sci USA. 2000; 97:7551-7555. [PubMed: 10861018]

41. Ogawa H, Nishi M, Kawata M. Localization of nuclear coactivators p300 and steroid receptor coactivator 1 in the rat hippocampus. Brain Res. 2001; 890:197-202. [PubMed: 11164785]

42. Nishihara E, Yoshida-Kimoya H, Chan C, Liao L, Davis RL, O'Malley BW, Xu J. SRC-1 null mice exhibit moderate motor dysfunction and delayed development of cerebellar Purkinje cells. J Neurosc. 2003; 23:213-222.

43. McGinnis MY, Lumia AR, Tetel MJ, Molenda-Figuiera HA, Possidente B. Effects of anabolic androgenic steroids on the development and expression of running wheel activity and circadian rhythms in male rats. Physiol Behav. 2007; 92:1010-1018. [PubMed: 17716697]

44. Charlier TD, Lakaye B, Ball GF, Balthazart J. Steroid receptor coactivator SRC-1 exhibits high expression in steroid-sensitive brain areas regulating reproductive behaviors in the quail brain. Neuroendocrinology. 2002; 76:297-315. [PubMed: 12457041]

45. Charlier TD, Balthazart J, Ball GF. Sex differences in the distribution of the steroid coactivator SRC-1 in the song control nuclei of male and female canaries. Brain Res. 2003; 959:263-274. [PubMed: 12493614]

46. Niessen NA, Balthazart J, Ball GF, Charlier TD. Steroid receptor coactivator 2 modulates steroiddependent male sexual behavior and neuroplasticity in Japanese quail (Coturnix japonica). J Neurochem. 2011; 119:579-593. [PubMed: 21854393] 
47. Duncan KA, Jimenez P, Carruth LL. Distribution and sexually dimorphic expression of steroid receptor coactivator-1 (SRC-1) in the zebra finch brain. Gen Comp Endocrinol. 2011; 170:408414. [PubMed: 21050854]

48. Apostolakis EM, Ramamurphy M, Zhou D, Onate S, O’Malley B. Acute disruption of select steroid receptor coactivators prevents reproductive behavior in rats and unmasks genetic adaptation in knockout mice. Mol Endocrinol. 2002; 16:1511-1523. [PubMed: 12089347]

49. Tetel MJ, Siegal NK, Murphy SD. Cells in behaviourally relevant brain regions coexpress nuclear receptor coactivators and ovarian steroid receptors. J Neuroendocrinol. 2007; 19:262-271. [PubMed: 17244199]

50. Camacho-Arroyo I, Neri-Gomez T, Gonzalez-Arenas A, Guerra-Araiza C. Changes in the content of steroid receptor coactivator-1 and silencing mediator for retinoid and thyroid hormone receptors in the rat brain during the estrous cycle. J Steroid Biochem Mol Biol. 2005; 94:267-272. [PubMed: 15862975]

51. Maerkel K, Durrer S, Henseler M, Schlumpf M, Lichtensteiger W. Sexually dimorphic gene regulation in brain as a target for endocrine disrupters: developmental exposure of rats to 4methylbenzylidene camphor. Toxicol Appl Pharmacol. 2007; 218:152-165. [PubMed: 17188730]

52. Mitev YA, Wolf SS, Almeida OF, Patchev VK. Developmental expression profiles and distinct regional estrogen responsiveness suggest a novel role for the steroid receptor coactivator SRC-1 as a discriminative amplifier of estrogen signaling in the rat brain. FASEB J. 2003; 17:518-519. [PubMed: 12551846]

53. Yore MA, Im D, Webb LK, Zhao Y, Chadwick JG Jr, Molenda-Figueira HA, Haidacher SJ, Denner L, Tetel M. Steroid receptor coactivator-2 expression in brain and physical associations with steriod receptors. Neuroscience. 2010; 169:1017-1028. [PubMed: 20678994]

54. Molenda-Figueira HA, Murphy SD, Shea KL, Siegal NK, Zhao Y, Chadwick JG Jr, Denner LA, Tetel J. Steroid receptor coactivator-1 from brain physically interacts differentially with steroid receptor subtypes. Endocrinology. 2008; 149:5272-5279. [PubMed: 18566116]

55. Molenda HA, Griffin AL, Auger AP, McCarthy MM, Tetel MJ. Nuclear receptor coactivators modulate hormone-dependent gene expression in brain and female reproductive behavior in rats. Endocrinology. 2002; 143:436-444. [PubMed: 11796496]

56. Molenda-Figueira HA, Williams CA, Griffin AL, Rutledge EM, Blaustein JD, Tetel MJ. Nuclear receptor coactivators function in estrogen receptor- and progestin receptor-dependent aspects of sexual behavior in female rats. Horm Behav. 2006; 50:383-392. [PubMed: 16769066]

57. Charlier TD. Importance of steroid receptor coactivators in the modulation of steroid action on brain and behavior. Psychoneuroendocrinology. 2009; 34:S20-S29. [PubMed: 19524371]

58. Duncan KA, Carruth LL. The song remains the same: coactivators and sex differences in the songbird brain. Front Neuroendocrinol. 2011; 32:84-94. [PubMed: 21094660]

59. Szego CM, Davis JS. Adenosine $3^{\prime}, 5^{\prime}$-monophosphate in rat uterus: acute elevation by estrogen. Proc Natl Acad Sci USA. 1967; 58:1711-1718. [PubMed: 4295833]

60. Kelly MJ, Moss RL, Dudley CA. Differential sensitivity of preoptic-septal neurons to microelectrophoresed estrogen during the estrous cycle. Brain Res. 1976; 114:152-157. [PubMed: 986858]

61. Micevych PE, Mermelstein PG. Membrane estrogen receptors acting through metabotropic glutamate receptors: an emerging mechanism of estrogen action in brain. Mol Neurobiol. 2008; 38:66-77. [PubMed: 18670908]

62. Filardo EJ, Quinn JA, Bland KI, Frackelton AR Jr. Estrogen-induced activation of Erk-1 and Erk-2 requires the G protein-coupled receptor homolog, GPR30, and occurs via trans-activation of the epidermal growth factor receptor through release of HB-EGF. Mol Endocrinol. 2000; 14:16491660. [PubMed: 11043579]

63. Singh M, Setalo G Jr, Guan X, Frail DE, Toran-Allerand CD. Estrogen-induced activation of the mitogen-activated protein kinase cascade in the cerebral cortex of estrogen receptor-alpha knockout mice. J Neurosci. 2000; 20:1694-1700. [PubMed: 10684871]

64. Qiu J, Bosch MA, Tobias SC, Grandy DK, Scanlan TS, Ronnekleiv OK, Kelly MJ. Rapid signaling of estrogen in hypothalamic neurons involves a novel G-protein-coupled estrogen receptor that activates protein kinase C. J Neurosci. 2003; 23:9529-9540. [PubMed: 14573532] 
65. Otto C, Rohde-Schulz B, Schwarz G, Fuchs I, Klewer M, Brittain D, Langer G, Bader B, Prelle K, Nubbemeyer R, Fritzemeier KH. G-protein-coupled receptor 30 localizes to the endoplasmic reticulum and is not activated by estradiol. Endocrinol. 2008; 149:4846-4856.

66. Mermelstein PG. Membrane-localised oestrogen receptor alpha and beta influence neuronal activity through activation of metabotropic glutamate receptors. J Neuroendocrinol. 2009; 21:257262. [PubMed: 19207809]

67. Levin ER. Minireview: Extranuclear Steroid Receptors: Roles in Modulation of Cell Functions. Mol Endocrinol. 2011; 25:377-384. [PubMed: 20861220]

68. Boulware MI, Kordasiewicz H, Mermelstein PG. Caveolin proteins are essential for distinct effects of membrane estrogen receptors in neurons. J Neurosci. 2007; 27:9941-9950. [PubMed: 17855608]

69. Grove-Strawser D, Boulware MI, Mermelstein PG. Membrane estrogen receptors activate the metabotropic glutamate receptors mGluR5 and mGluR3 to bidirectionally regulate CREB phosphorylation in female rat striatal neurons. Neuroscience. 2010; 170:1045-1055. [PubMed: 20709161]

70. Lonze BE, Ginty DD. Function and regulation of CREB family transcription factors in the nervous system. Neuron. 2002; 35:605-623. [PubMed: 12194863]

71. Gu Q, Moss RL. 17 beta-Estradiol potentiates kainate-induced currents via activation of the cAMP cascade. J Neurosci. 1996; 16:3620-3629. [PubMed: 8642406]

72. Wade CB, Dorsa DM. Estrogen activation of cyclic adenosine $5^{\prime}$-monophosphate response element-mediated transcription requires the extracellularly regulated kinase/mitogen-activated protein kinase pathway. Endocrinology. 2003; 144:832-838. [PubMed: 12586759]

73. Lee SJ, Campomanes CR, Sikat PT, Greenfield AT, Allen PB, McEwen BS. Estrogen induces phosphorylation of cyclic AMP response element binding (pCREB) in primary hippocampal cells in a time-dependent manner. Neuroscience. 2003; 124:549-560. [PubMed: 14980726]

74. Abraham IM, Todman MG, Korach KS, Herbison AE. Critical in vivo roles for classical estrogen receptors in rapid estrogen actions on intracellular signaling in mouse brain. Endocrinology. 2004; 145:3055-3061. [PubMed: 14976146]

75. Boulware MI, Weick JP, Becklund BR, Kuo SP, Groth RD, Mermelstein PG. Estradiol activates group I and II metabotropic glutamate receptor signaling, leading to opposing influences on cAMP response element-binding protein. J Neurosci. 2005; 25:5066-5078. [PubMed: 15901789]

76. Mermelstein PG, Becker JB, Surmeier DJ. Estradiol reduces calcium currents in rat neostriatal neurons via a membrane receptor. J Neurosci. 1996; 16:595-604. [PubMed: 8551343]

77. Balthazart J, Ball GF. Is brain estradiol a hormone or a neurotransmitter? Trends Neurosci. 2006; 29:241-249. [PubMed: 16580076]

78. Schlinger BA, Callard GV. Localization of aromatase in synaptosomal and microsomal subfractions of quail (Coturnix coturnix japonica) brain. Neuroendocrinology. 1989; 49:434-441. [PubMed: 2716959]

79. Hojo Y, Hattori TA, Enami T, Furukawa A, Suzuki K, Ishii HT, Mukai H, Morrison JH, Janssen WG, Kominami S, Harada N, Kimoto T, Kawato S. Adult male rat hippocampus synthesizes estradiol from pregnenolone by cytochromes P45017alpha and P450 aromatase localized in neurons. Proc Natl Acad Sci USA. 2004; 101:865-870. [PubMed: 14694190]

80. Srivastava DP, Woolfrey KM, Liu F, Brandon NJ, Penzes P. Estrogen receptor b activity modulates synaptic signaling and structure. J Neurosci. 2010; 30:13454-13460. [PubMed: 20926671]

81. Srivastava DP, Waters EM, Mermelstein PG, Kramar EA, Shors TJ, Liu F. Rapid Estrogen Signaling in the Brain: Implications for the Fine-Tuning of Neuronal Circuitry. J Neurosci. 2011; 31:16056-16063. [PubMed: 22072656]

82. Pedram A, Razandi M, Sainson RC, Kim JK, Hughes CC, Levin ER. A conserved mechanism for steroid receptor translocation to the plasma membrane. J Biol Chem. 2007; 282:22278-22288. [PubMed: 17535799]

83. Acconcia F, Ascenzi P, Bocedi A, Spisni E, Tomasi V, Trentalance A, Visca P, Marino M. Palmitoylation-dependent estrogen receptor alpha membrane localization: regulation by 17 betaestradiol. Mol Biol Cell. 2005; 16:231-237. [PubMed: 15496458] 
84. Marino M, Ascenzi P, Acconcia F. S-palmitoylation modulates estrogen receptor alpha localization and functions. Steroids. 2006; 71:298-303. [PubMed: 16274718]

85. Dewing P, Boulware MI, Sinchak K, Christensen A, Mermelstein PG, Micevych P. Membrane estrogen receptor-alpha interactions with metabotropic glutamate receptor 1a modulate female sexual receptivity in rats. J Neurosci. 2007; 27:9294-9300. [PubMed: 17728443]

86. Kuo J, Hamid N, Bondar G, Prossnitz ER, Micevych P. Membrane estrogen receptors stimulate intracellular calcium release and progesterone synthesis in hypothalamic astrocytes. J Neurosci. 2010; 30:12950-12957. [PubMed: 20881113]

87. Chaban V, Li J, McDonald JS, Rapkin A, Micevych P. Estradiol attenuates the adenosine triphosphate-induced increase of intracellular calcium through group II metabotropic glutamate receptors in rat dorsal root ganglion neurons. J Neurosci Res. 2011; 89:1707-1710. [PubMed: 21793040]

88. Wright CL, McCarthy MM. Prostaglandin E2-induced masculinization of brain and behavior requires protein kinase A, AMPA/kainate, and metabotropic glutamate receptor signaling. J Neurosci. 2009; 29:13274-13282. [PubMed: 19846715]

89. Christensen A, Dewing P, Micevych P. Membrane-initiated estradiol signaling induces spinogenesis required for female sexual receptivity. J Neurosci. 2011; 31:17583-17589. [PubMed: 22131419]

90. Woolley, CS. Rapid synaptic actions of estrogens. Society of Neuroscience Annual Meeting; 2011.

91. Becker JB. personal communication. 2011

92. Glebova NO, Ginty DD. Growth and survival signals controlling sympathetic nervous system development. Annu Rev Neurosci. 2005; 28:191-222. [PubMed: 16022594]

93. Vanderhorst VG, Gustafsson JA, Ulfhake B. Estrogen receptor-alpha and -beta immunoreactive neurons in the brainstem and spinal cord of male and female mice: relationships to monoaminergic, cholinergic, and spinal projection systems. J Comp Neurol. 2005; 488:152-179. [PubMed: 15924341]

94. Anesetti G, Lombide P, Chavez-Genaro R. Prepubertal estrogen exposure modifies neurotrophin receptor expression in celiac neurons and alters ovarian innervation. Auton Neurosci. 2009; 145:35-43. [PubMed: 19036644]

95. Papka RE, Storey-Workley M, Shughrue PJ, Merchenthaler I, Collins JJ, Usip S, Saunders PT, Shupnik M. Estrogen receptor-alpha and beta-immunoreactivity and mRNA in neurons of sensory and autonomic ganglia and spinal cord. Cell Tissue Res. 2001; 304:193-214. [PubMed: 11396714]

96. Vega Orozco AS, Daneri C, Anesetti G, Cabrera R, Sosa Z, Rastrilla AM. Involvement of the oestrogenic receptors in superior mesenteric ganglion on the ovarian steroidogenesis in rat. Reproduction. 2012; 143:183-193. [PubMed: 22080140]

97. Varayoud J, Ramos JG, Monje L, Bosquiazzo V, Muñoz-de-Toro M, Luque EH. The estrogen receptor a $\Sigma 3$ mRNA splicing variant is differentially regulated by estrogen and progesterone in the rat uterus. J Endocrinol. 2005; 186:51-60. [PubMed: 16002535]

98. Hazell GGJ, Yao ST, Roper JA, Prossnitz ER, O'Carroll A-M, Lolait SJ. Localisation of GPR30, a novel $\mathrm{G}$ protein-coupled oestrogen receptor, suggests multiple functions in rodent brain and peripheral tissues. J Endocrinol. 2009; 202:223-236. [PubMed: 19420011]

99. Lawrence IE Jr, Burden HW. The origin of the extrinsic adrenergic innervation to the rat ovary. Anat Rec. 1980; 196:51-59. [PubMed: 7416501]

100. Ahmed CE, Dees WL, Ojeda SR. The immature rat ovary is innervated by vasoactive intestinal peptide (VIP)-containing fibers and responds to VIP with steroid secretion. Endocrinology. 1986; 118:1682-1689. [PubMed: 3512260]

101. Lara HE, McDonald JK, Ahmed CE, Ojeda SR. Guanethidine-mediated destruction of ovarian sympathetic nerves disrupts ovarian development and function in rats. Endocrinology. 1990; 127:2199-2209. [PubMed: 1977580]

102. Mayerhofer A, Dissen GA, Costa ME, Ojeda SR. A role for neurotransmitters in early follicular development: induction of functional follicle-stimulating hormone receptors in newly formed follicles of the rat ovary. Endocrinology. 1997; 138:3320-3329. [PubMed: 9231784] 
103. Couse JF, Yates MM, Deroo BJ, Korach KS. Estrogen receptor-beta is critical to granulosa cell differentiation and the ovulatory response to gonadotropins. Endocrinology. 2005; 146:32473262. [PubMed: 15831568]

104. Woodruff TK, Mayo KE. To beta or not to beta: estrogen receptors and ovarian function. Endocrinology. 2005; 146:3244-3246. [PubMed: 16009972]

105. Lara HE, Hill DF, Katz KH, Ojeda SR. The Gene Encoding Nerve Growth Factor Is Expressed in the Immature Rat Ovary: Effect of Denervation and Hormonal Treatment. Endocrinology. 1990; 126:357-363. [PubMed: 2293993]

106. Reichardt LF. Neurotrophin-regulated signalling pathways. Philosophical Transactions of the Royal Society B: Biol Sci. 2006; 361:1545-1564.

107. Sohrabji F, Miranda RC, Toran-Allerand CD. Identification of a putative estrogen response element in the gene encoding brain-derived neurotrophic factor. Proc Natl Acad Sci USA. 1995; 92:11110-11114. [PubMed: 7479947]

108. Bjorling DE, Beckman M, Clayton MK, Wang ZY. Modulation of nerve growth factor in peripheral organs by estrogen and progesterone. Neuroscience. 2002; 110:155-167. [PubMed: 11882380]

109. Richeri A, Bianchimano P, Marmol NM, Viettro L, Cowen T, Brauer MM. Plasticity in rat uterine sympathetic nerves: the role of TrkA and $\mathrm{p} 75$ nerve growth factor receptors. J Anat. 2005; 207:125-134. [PubMed: 16050899]

110. Chavez-Genaro R, Lombide P, Anesetti G. A quantitative study of rat uterine sympathetic innervation during pregnancy and post partum. Reprod Fertil Dev. 2006; 18:525-531. [PubMed: 16836959]

111. Lara HE, Dissen GA, Leyton V, Paredes A, Fuenzalida H, Fiedler JL, Ojeda SR. An Increased Intraovarian Synthesis of Nerve Growth Factor and Its Low Affinity Receptor Is a Principal Component of Steroid-Induced Polycystic Ovary in the Rat. Endocrinology. 2000; 141:10591072. [PubMed: 10698182]

112. Sotomayor-Zarate R, Dorfman M, Paredes A, Lara HE. Neonatal exposure to estradiol valerate programs ovarian sympathetic innervation and follicular development in the adult rat. Biol Reprod. 2008; 78:673-680. [PubMed: 18077802]

113. Franks S, Stark J, Hardy K. Follicle dynamics and anovulation in polycystic ovary syndrome. Human Reprod Update. 2008; 14:367-378.

114. Lara HE, Dorfman M, Venegas M, Luza SM, Luna SL, Mayerhofer A, Guimaraes MA, Rosa ESAA, Ramirez VD. Changes in sympathetic nerve activity of the mammalian ovary during a normal estrous cycle and in polycystic ovary syndrome: Studies on norepinephrine release. Microsc Res Tech. 2002; 59:495-502. [PubMed: 12467025]

115. Heider U, Pedal I, Spanel-Borowski K. Increase in nerve fibers and loss of mast cells in polycystic and postmenopausal ovaries. Fertil Steril. 2001; 75:1141-1147. [PubMed: 11384640]

116. Donesky BW, Adashi EY. Surgically induced ovulation in the polycystic ovary syndrome: wedge resection revisited in the age of laparoscopy. Fertil Steril. 1995; 63:439-463. [PubMed: 7851570]

\section{Abbreviations}

$\begin{array}{ll}\text { CBP } & \text { CREB binding protein } \\ \text { CRE } & \text { CREB response element } \\ \text { DAR } & \text { Dopamine receptor (DAR) } \\ \text { ER } & \text { Estrogen receptor } \\ \text { ERE } & \text { Estrogen response element } \\ \text { mGluR } & \text { Metabotropic glutamate receptor } \\ \text { PGMRC1 } & \text { Progesterone membrane receptor component 1 }\end{array}$

PR Progestin receptor 
PRE

SRCs
Progestin response element

Steroid receptor coactivators 


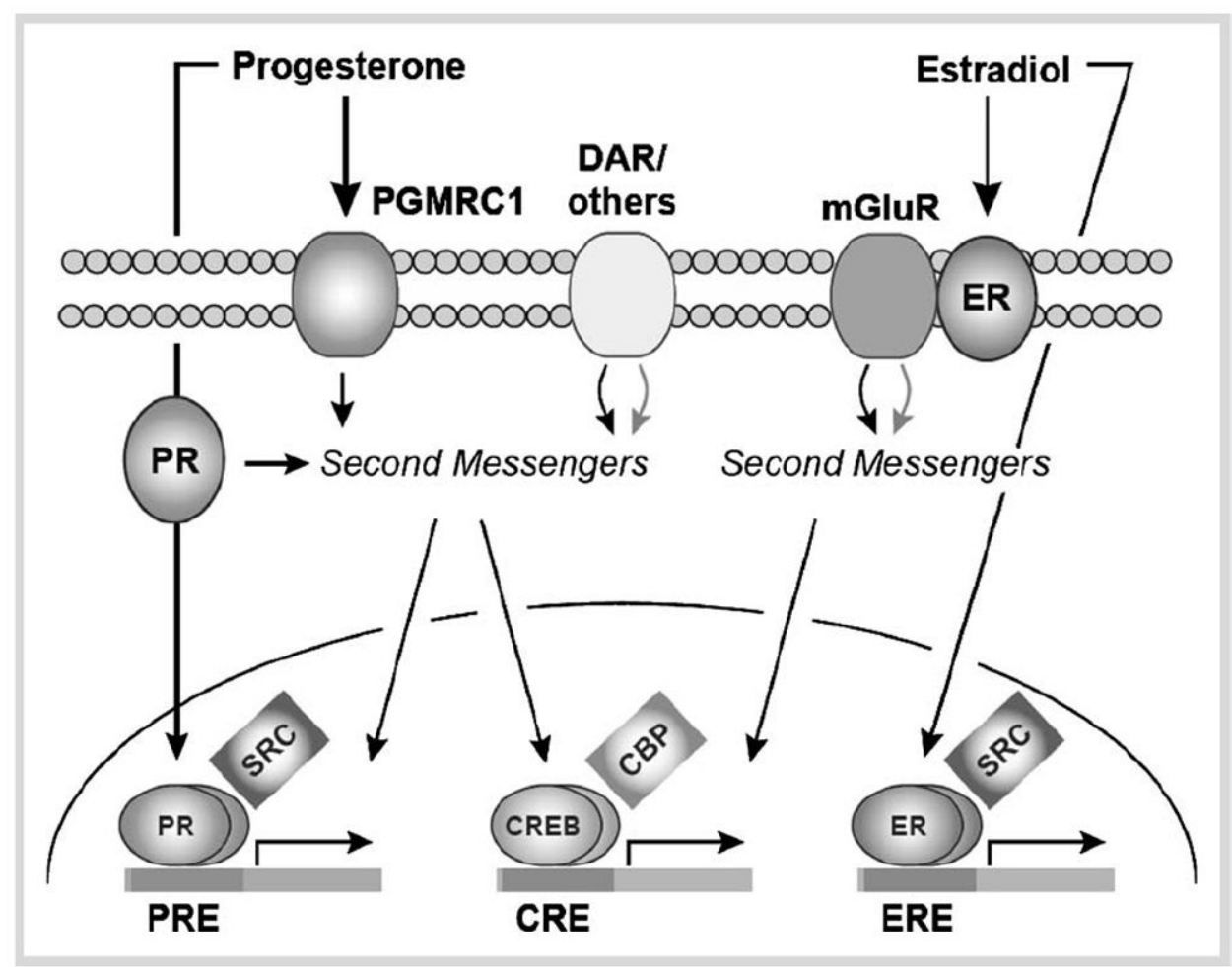

Fig. 1.

Convergence of progesterone- and estradiol-mediated signaling in the nervous system. Through membrane, cytosolic, and intracellular receptors, these hormones affect surface membrane signaling, second messenger systems, and gene expression. Transcriptional cofactors are also intimately involved in the regulation of classical, steroid hormone-mediated as well as activity-dependent gene expression. 